\title{
Islet cell surface and lymphocyte antibodies often precede the spontaneous diabetes in the $\mathrm{BB}$ rat
}

\author{
T. Dyrberg ${ }^{1}$, P. Poussier ${ }^{2}$, F. Nakhooda ${ }^{2}$, E. B. Marliss ${ }^{2}$ and Å. Lernmark ${ }^{1}$

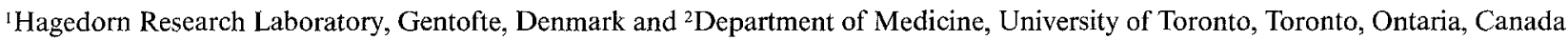

\begin{abstract}
Summary. The diabetic syndrome of the BB rat shows many homologies with that of human insulin-dependent diabetes and evidence that the onset of the disease is associated with the presence of autoantibodies, including islet cell surface antibodies. In this study, sera were sampled serially from weaning to 157 days of age from $26 \mathrm{BB}$ rats in two low-incidence litters, and 22 rats of three high-incidence litters. Clinical and metabolic variables were monitored concurrently with blood lymphocyte counts. Islet morphology was correlated at sacrifice. In the high-incidence litters, eight rats developed insulin-dependent diabetes, five impaired glucose tolerance, and the remaining nine all showed insulitis. In the low-incidence litters, only one animal showed impaired glucose tolerance and another insulitis. In the high-incidence litters 16 rats $(73 \%)$ had islet cell surface antibodies compared with 4 out of $26(15 \%)$ low-incidence controls $(p<0.002)$. Antibodies reactive with Wistar rat spleen lymphocytes were present in all
\end{abstract}

high-incidence rats compared with $19 \%$ (5 out of 26 ) among the control litters $(p<0.002)$. Time courses of islet cell surface and lymphocyte antibody appearance and their peak values varied, but already at weaning the levels of both antibodies were increased among the high-incidence litter rats $(p<$ 0.001 ). Islet cell surface and/or lymphocyte antibodies were therefore present in the majority of animals at an age where neither morphological nor metabolic evidence of the diabetic syndrome were yet detected. All rats that showed any form of the syndrome were lymphopenic. These findings suggest that BB rats have an abnormal immune response which predisposes to later development of insulin-dependent diabetes, often preceded by the presence of islet cell surface and/or lymphocyte antibodies.

Key words: BB rats, islet cell surface antibodies, lymphocyte antibodies.
The BB rat develops insulitis and insulin-dependent diabetes mellitus with many features analogous to that of the human disease [1-3] including the possibility that cell-mediated and humoral immunological mechanisms are associated with development of the diabetic syndrome [3]. Evidence for altered cell-mediated immunity includes (a) mononuclear cell infiltrates in the islets [1-3], (b) marked lymphocytopenia in blood as well as in lymphoid organs $[4,5]$ associated with an abnormal mitogenic response of remaining $\mathrm{T}$ lymphocytes $[6,7]$, (c) possible prevention of the syndrome by either neonatal thymectomy [8], antilymphocyte serum [9], cyclosporin [10]; bone marrow transplantation [11] or by transfusion of blood from normal rats [7], and (d) passive transfer of insulitis by lymphocytes from diabetic rats to nude mice [12]. Evidence for an altered humoral immune function in diabetic $\mathrm{BB}$ rats includes the presence of circulating islet cell surface antibodies (ICSA) and antibodies to splenic lymphocytes [13] as well as antibodies to thyroid, smooth muscle, and gastric parietal cells [14-16]. The above investigations suggest that diabetes develops in animals with a defective immune system, which is emphasized by the observations that lymphocytopenia [4], impaired glucose tolerance [3, 17] and autoantibodies [16] may all antedate the clinical onset of insulin-dependent diabetes. Since the latter is accompanied by a decrease in pancreatic islet beta cells [3, 15], it was important to establish whether circulating antibodies reactive with islet cell determinants were present also before the onset of diabetes. Therefore, we have tested whether circulating ICSA and lymphocyte antibodies correlate to the development of impaired glucose tolerance or overt diabetes in rats from litters with either low or high incidence of diabetes, followed prospectively from weaning to 157 days of age.

\section{Materials and methods}

\section{Animals and metabolic studies}

The BB rats were obtained from Dr. P. Thibert, Animal Resources Division, Health Protection Branch, Ottawa, Canada. Twenty-two rats from three litters ( 12 males and 10 females), with an expected high incidence of diabetes $(\sim 70 \%$ in the generation preceding the animals 
studied), and two litters with 26 rats (13 males, 13 females) with an expected low incidence $(<5 \%)$ were followed from $38-53$ to 142-157 days of age. After weaning the animals were kept in individual metabolic cages in a light-, temperature-, and humidity-controlled facility, and fed Purina Lab Chow (Ralston-Purina, Woodstock, Ontario, Canada) and water ad libitum. Body weight, urine output, glycosuria, and clinical appearance were monitored daily. When glycosuria was detected, insulin therapy was initiated, the insulin dose being modulated according to glycosuria, body weight, and intermittently monitored glycaemia of each rat. Blood samples were drawn biweekly from the orbital sinus under light ether anaesthesia. At monthly intervals, either an oral (intragastric, $0.25 \mathrm{mg} / \mathrm{g}$ body weight) or IP $(0.20 \mathrm{mg} / \mathrm{g}$ body weight $)$ glucose tolerance test was performed in nondiabetic animals. In the oral test, samples were drawn from the orbital sinus at 0,60 , and $120 \mathrm{~min}$, and in the IP test from the tail vein without anaesthesia at 0 and $60 \mathrm{~min}$. The range of normal values for the oral glucose tolerance test was established previously in non-diabetic BB and non-BB Wistar rats [17]. A value $>14 \mathrm{mmol} / 1$ at $60 \mathrm{~min}$ was considered as an indication of impaired glucose tolerance. Blood samples collected in the presence of EDTA were used for the determination of total white blood cells using a Coulter Counter (Coulter Electronics, St. Albans, Herts, UK) and differential counts were recorded from routinely stained smears. Plasma glucose was determined by the glucose oxidase method using a Beckman Glucose Analyzer 11 (Beckman Instruments, Fullerton, California). Sera were collected for antibody determinations and stored at $-20^{\circ} \mathrm{C}$ until the longitudinal study was complete in all animals. None of the rats developed apparent infections or complications due to sampling or therapy.

\section{Culture and preparation of the RIN $5 F$ cells}

RIN 5F cells, an insulin-producing cell-line developed from a transplantable rat islet cell tumour [18] were kindly donated by Drs. H. Oie and A. Gázdar (National Cancer Institute, Washington, DC, USA). The RIN $5 \mathrm{~F}$ cells were kept at $37^{\circ} \mathrm{C}$ in monolayer culture in RPMI 1640 medium (Grand Island Biological Company, Grand Island, New York) supplemented with $10 \%$ fetal calf serum in an atmosphere of $5 \% \mathrm{CO}_{2}$. When the cells were near confluency they were rinsed and incubated for $60 \mathrm{~min}$ at $37^{\circ} \mathrm{C}$ in $\mathrm{Ca}^{++}$and $\mathrm{Mg}^{++}$-free Hank's balanced salt solution. After incubation, the cells were dissociated by gentle aspiration with a pasteur pipette and washed twice by centrifugation $(50 \mathrm{~g}$ for $10 \mathrm{~min}$ ) in $10 \mathrm{mmol} / 1 \mathrm{~N}$-hydroxy-ethylpiperazine$\mathrm{N}^{\prime}$-2-ethane-sulphonic acid (Hepes) containing $\mathrm{NaCl}(140 \mathrm{mmol} / \mathrm{l})$ and $1 \% \mathrm{w} / \mathrm{v}$ bovine serum albumin (HNB-buffer, $\mathrm{pH} 7.4$ ). The cells were fixed at $4{ }^{\circ} \mathrm{C}$ for $60 \mathrm{~min}$ in HNB-buffer supplemented with $4 \%$ $(w / v)$ paraformaldehyde [19]. The fixed cells were washed twice by centrifugation in HNB-buffer, stored in HNB-buffer with $\mathrm{NaN}_{3}$ $(15 \mathrm{mmol} / 1)$ and used within 14 days. The number of cells was determined in a haemocytometer and the viability of non-fixed cells by double fluorescence staining with ethidium bromide and acridine orange. In 11 subsequent cell preparations representing a total of $362 \times 10^{6}$ cells, the mean viability was $87 \%$. There were $53 \pm 22 \%$ (mean $\pm \mathrm{SD}$ ) single cells; however, clumps of more than 10 cells were rarely seen.

In one series of experiments we used RIN $14 \mathrm{~B}$ cells, another continuous somatostatin-producing cell-line (Oie and Gázdar, personal communication), derived from the same rat islet cell tumour as the RIN 5F cells. RIN 14B cells were cultured and fixed as described for RIN $5 F$ cells.

\section{Preparation of pancreatic islet cells}

The cells were prepared from islets isolated by collagenase digestion of the pancreas $[20,21]$. Male Wistar rats, weight 90-100 g (Møllegårdens Avlscenter, Ejby, Denmark), were fasted overnight and killed by cervical dislocation. The pancreatic islets were isolated by repeated collagenase digestion combined with centrifugation through a discontinuous Percoll gradient [22]. The islets were collected under a stereomicroscope and incubated for $30 \mathrm{~min}$ at $22^{\circ} \mathrm{C}$ in RPMI 1640 medium containing EGTA ( $2 \mathrm{mmol} / \mathrm{l}$ ) before dissociation into single cells by aspiration through a constricted pasteur pipette [22]. The cell suspension was layered on top of $10 \mathrm{ml}$ of RPMI 1640 tissue culture medium with $4 \%$ bovine serum albumin and centrifuged $\left(50 \mathrm{~g}\right.$ at $4{ }^{\circ} \mathrm{C}$ for $15 \mathrm{~min}$ ) to remove cellular debris. Finally, the islet cells were resuspended in the same medium and fixed in HNB buffer with $4 \%(\mathrm{w} / \mathrm{v})$ paraformaldehyde [19]. In four experiments with a total of 26 rats, $125 \times 10^{3}$ islet cells per rat were obtained with a mean viability of $87 \%$ and representing $79 \pm 14 \%$ (mean $\pm \mathrm{SD}$ ) single cells.

\section{Preparation of lymphocytes}

The spleens from male Wistar rats, weighing $\sim 100 \mathrm{~g}$, were sliced and pressed through a sterile nylon mesh into ice-cold Hank's balanced salt solution. The resulting cell suspension was layered onto a FicollHypaque gradient (Pharmacia Fine Chemicals, Uppsala, Sweden) and centrifuged at $4^{\circ} \mathrm{C}$ for $15 \mathrm{~min}$ at $800 \mathrm{~g}$ [23]. The interface, containing the lymphocytes, was collected and the cells washed twice by centrifugation in HNB-buffer before fixing and storing as described above for the RIN $5 \mathrm{~F}$ cells. The viability before fixation was $>95 \%$ in all experiments.

\section{Preparation of tracers}

Protein A (Pharmacia Fine Chemicals, Uppsala, Sweden) was iodinated with chloramine-T and purified by polyacrylamide disc gel electrophoresis as described [22] (spec. act. $30 \mathrm{Ci} / \mathrm{g}$ ). An affinity purified rabbit anti-rat immunoglobulin (Sera Lab Ltd. Crawley Down, Sussex, UK) was iodinated with chloramine-T [22] and separated from the free iodine by gel filtration on Sephadex G-25, fine (Pharmacia Fine Chemicals)

\section{${ }^{125}$ I-protein A radioligand assay}

Islet cell surface antibodies (ICSA) and lymphocyte antibodies were determined $[13,19]$ in coded samples of sera, which were heat-inactivated $\left(30 \mathrm{~min}\right.$ at $\left.56^{\circ} \mathrm{C}\right)$ and centrifuged $(5 \mathrm{~min}$ at $10,000 \mathrm{~g})$. The supernatants were aliquoted and stored at $-20^{\circ} \mathrm{C}$ allowing each sample to be thawed only once. In the assays for surface antibodies, $100 \mu \mathrm{l}$ paraformaldehyde-fixed cells $\left(1 \times 10^{6} \mathrm{RIN} 5 \mathrm{~F}\right.$ cells $/ \mathrm{ml}$ or $20 \times 10^{6} \mathrm{lym}$ phocytes $/ \mathrm{ml}$ ) were incubated in $1.5 \mathrm{ml}$ polypropylene tubes for $60 \mathrm{~min}$ at $4^{\circ} \mathrm{C}$ with $100 \mu \mathrm{l}$ serum sample at a final dilution of $1: 24$ in HNB-buffer (optimum dilution for discrimination between antibody positive and negative samples). The cells were washed in HNB-buffer $(1.3 \mathrm{ml})$ and after centrifugation $(45 \mathrm{~s}, 10,000 \mathrm{~g})$, the cell pellet $(\sim 25 \mu \mathrm{l})$ was resuspended in $50 \mu \mathrm{l}{ }^{125} \mathrm{I}$-protein $\mathrm{A}\left(6 \times 10^{6} \mathrm{cpm} / \mathrm{ml}\right)$, prepared as described [22], in HNB-buffer. After incubation for $30 \mathrm{~min}$ at $4^{\circ} \mathrm{C}$, HNB-buffer $(1.5 \mathrm{ml})$ was added and the cells washed twice by centrifugation at $10,000 \mathrm{~g}$, first for $45 \mathrm{~s}$ and then for $90 \mathrm{~s}$. The bottom of each tube containing the cell pellet in $\sim 25 \mu 1$ was cut out and counted in a gamma counter (Tracor Analytical Model 1285, Searle, Des Plains, Illinois) to determine cell-bound radioactivity. All results are the mean of duplicate determinations. The precision of the assay, calculated as the intra-assay coefficient of variation: $\frac{100 \times\left(x_{1}-x_{2}\right) / 1.128}{\left(x_{1}+x_{2}\right) / 2}$ [24] was $15 \%$ in 28 assays. The reproducibility tested on sera samples from three BB rats, randomly selected from low-incidence litters, was $31 \%$ in 27 consecutive assays.

\section{Correlation between binding of protein $A$ and antibodies against rat immunoglobulin $G$}

The binding capacity of ${ }^{125} \mathrm{I}$-protein $\mathrm{A}$ to rat immunoglobulins is low compared to that of man, dog or rabbit $[25,26]$. In separate control experiments, ${ }^{125} \mathrm{I}$-labelled rabbit IgG directed against rat IgG was tested in parallel with ${ }^{125} \mathrm{I}$-protein $\mathrm{A}$ in the radioligand assay. In randomly 


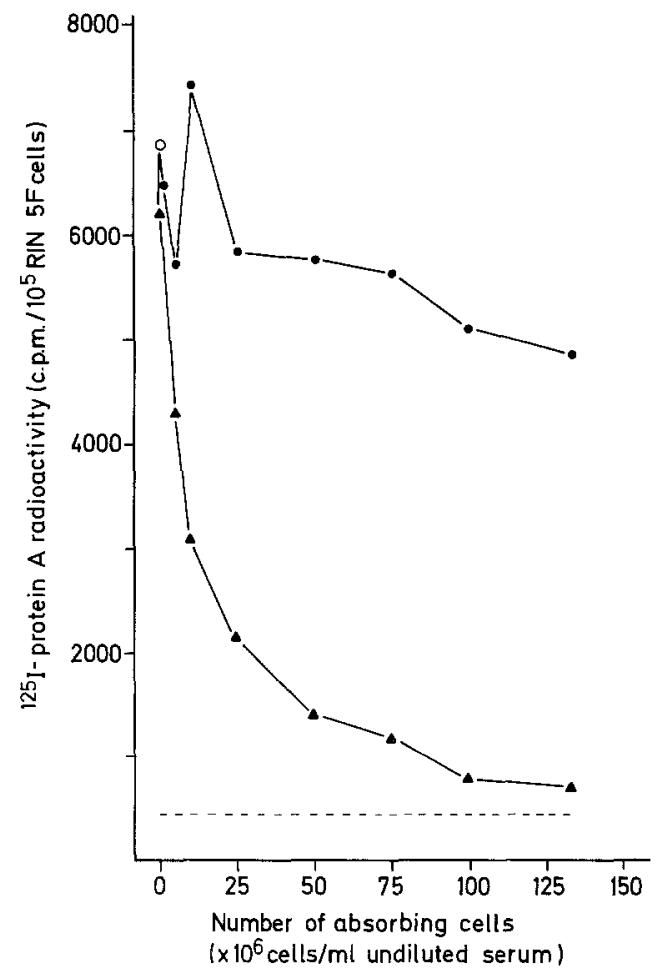

Fig. 1. Quantitative adsorption of a BB rat islet cell surface antibody positive serum with increasing numbers of either splenic lymphocytes $(\boldsymbol{O})$ or RIN 5F cells $(\Delta)$. The unadsorbed $(\mathrm{O})$ and adsorbed sera were incubated at a final dilution of $1 / 20$ with $10^{5}$ RIN $5 \mathrm{~F}$ cells and the cell surface bound antibody estimated by incubation with ${ }^{125}$ I-protein A - . . . - represents binding using sera (diluted 1/20) from nondiabetes susceptible $\mathrm{BB}$ rats

Table 1. ${ }^{125}$ I-protein A binding to different cell types incubated in sera from BB rats with low or high incidence of insulin-dependent diabetes

\begin{tabular}{clcl}
\hline & \multicolumn{3}{l}{${ }^{125}$ I-protein A radioactivity (cpm/10 cells) } \\
\cline { 2 - 4 } & RIN 5F & RIN 14B & Lymphocytes \\
\hline $\begin{array}{c}\text { Low-incidence rats } \\
(n=6)\end{array}$ & $1036 \pm 346$ & $929 \pm 145$ & $1125 \pm 366$ \\
$\begin{array}{l}\text { High-incidence rats } \\
(n=12)\end{array}$ & $4876 \pm 3811$ & $\begin{array}{l}3540 \pm 3191 \\
\text { NS }\end{array}$ & $\begin{array}{l}2248 \pm 3032 \\
\text { NS }\end{array}$ \\
\hline
\end{tabular}

Mean values \pm SD are shown. $p$ values indicate binding values different from those of the RIN 5F cells in a paired Student's t-test

selected sera samples from 17 diabetic and non-diabetic $B B$ rats, the binding of ${ }^{125} \mathrm{I}$-protein $\mathrm{A}$ correlated to that of ${ }^{125} \mathrm{I}$-rabbit anti-rat IgG $(r=0.9286 ; p<0.001)$, which suggests that bound protein A radioactivity reflects binding of rat immunoglobulin to the RIN $5 \mathrm{~F}$ cells.

\section{Correlation between ${ }^{125}$ I-protein A binding to islet cells and RIN $5 F$ cells}

A highly significant correlation between the binding of ${ }^{125}$ I-protein A to paraformaldehyde-fixed RIN $5 \mathrm{~F}$ cells and normal rat islet cells incubated with sera from BB rats was demonstrated in a previous study [27]. In two experiments we repeated this test by incubating Wistar rat islet cells and RIN $5 \mathrm{~F}$ cells in sera samples from BB rats from the lowincidence $(n=7)$ and high-incidence $(n=10)$ litters. In both experiments the binding of ${ }^{125} \mathrm{I}$-protein $\mathrm{A}$ to islet cells correlated to that of RIN 5F cells $(r=0.99, p<0.001)$.

\section{Specificity of islet cell surface antibodies and lymphocyte antibodies}

Since BB rats have circulating antibodies reactive with a variety of tissues [14-16], the presence of cell surface antibodies may represent antibodies against common rat cell membrane determinants. This possibility was excluded in a quantitative adsorption test shown in Figure 1. An antibody-positive BB rat sample was first adsorbed [22] to either RIN $5 \mathrm{~F}$ cells or spleen lymphocytes $\left(0-130 \times 10^{6}\right.$ cells $/ \mathrm{ml} \mathrm{se-}$ rum). RIN $5 F$ cells were then incubated in the resulting supernatants and the binding of ${ }^{125} \mathrm{I}$-protein $\mathrm{A}$ determined as described above. The results demonstrate that $100-130 \times 10^{6} \mathrm{RIN} 5 \mathrm{~F}$ cells $/$ ml quantitatively removed antibodies binding to RIN 5F cells (Fig.1). In contrast, $100-130 \times 10^{6}$ lymphocytes $/ \mathrm{ml}$ decreased the subsequent binding of antibodies to RIN $5 \mathrm{~F}$ cells by $\sim 30 \%$ only. These control experiments suggest that antibodies reactive with both cell types may be present but that ICSA occur independently of lymphocyte antibodies. All 400 sera samples were therefore analyzed for both ICSA and lymphocyte antibodies without prior adsorption.

RIN 5F cells, RIN 14B cells, and lymphocytes were incubated in parallel with sera from 12 high-incidence and six low-incidence rats to further evaluate the specificity of the ${ }^{125}$ I-protein A binding (Table 1). The binding of ${ }^{125}$ I-protein A to RIN $5 \mathrm{~F}$ cells was significantly higher than to RIN 14B cells in sera from high-incidence litters, but not lowincidence animals (Table 1). RIN 5F cells bound more than twice as much ${ }^{125}$ I-protein A as spleen lymphocytes in sera of high-incidence rats, but there was no difference between these bindings in sera from the low-incidence litter animals (Table 1).

\section{Morphological studies}

At the end of the prospective study (142-157 days) the rats were sacrificed and the pancreas quickly excised, fixed in Bouin's solution and embedded in paraffin $[1,17]$. Sections were stained with hematoxylin and eosin or with glutaraldehyde fuchsin and all samples were coded before evaluation by light microscopy as described $[1,17]$.

\section{Statistics}

Statistical analyses were performed using Fisher's exact test, Student's t-test, either paired or unpaired, or by calculating the correlation coefficient $r$ for linear relationships.

\section{Results}

\section{Clinical and metabolic studies}

Among 26 rats of the two low-incidence litters one animal showed impaired glucose tolerance and another insulitis. None of the animals developed insulin-dependent diabetes. All 22 rats of the three high-incidence litters showed abnormalities: eight developed insulindependent diabetes with typical end-stage islets [1, 3], five showed impaired glucose tolerance with insulitis, and nine showed unequivocal but milder insulitis without glucoregulatory disturbances. Insulin-dependent diabetes occurred between the ages of 72 and 131 days (mean 95 days). Glycaemic and morphological data are 

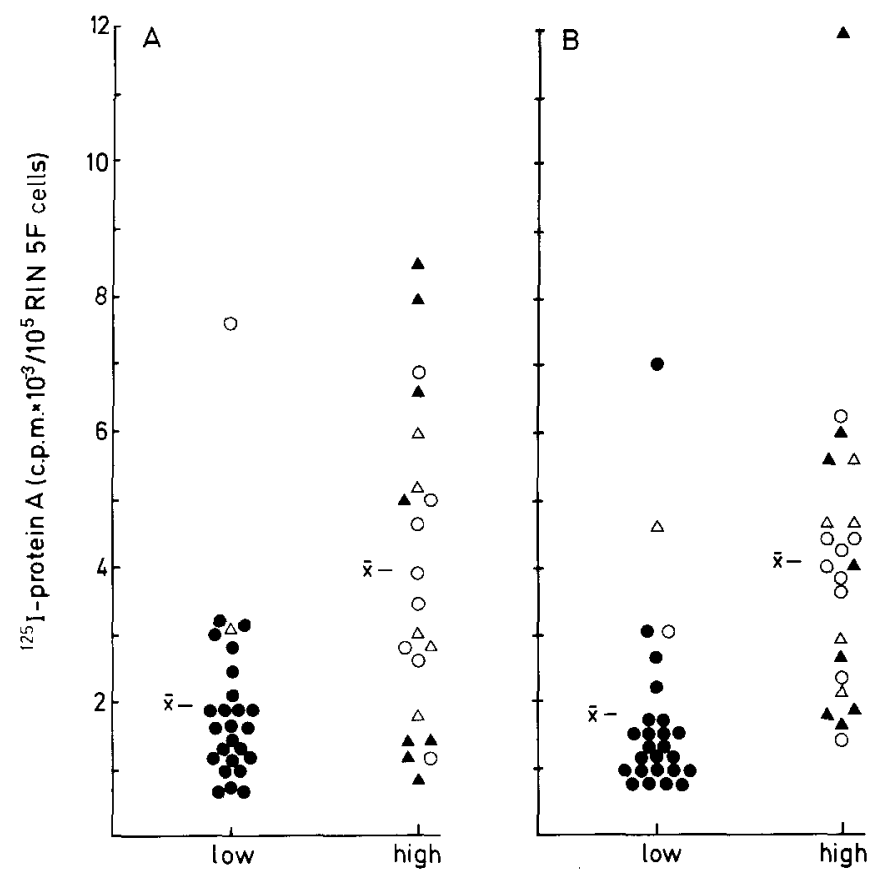

Expected incidence of diabetes

Fig. 2. Panel A: binding of ${ }^{125}$ I-protein A to RIN 5F cells incubated with sera from low- and high-incidence BB rats aged 48-53 days. Panel B: mean binding of 6-10 separate determinations in sera (final dilution 1:24) sampled bimonthly throughout the study period (38-157 days of age) is shown. The symbols indicate animals without (O) or at the end of study (142-157 days of age) with either insulindependent diabetes $(\Delta)$, impaired glucose tolerance test $(\Delta)$ or insulitis $(O)$. The mean values $(\bar{x})$ for low- and high-incidence rats were significantly different in both age ranges $(p<0.001)$

not shown, but correspond to our previously published results in animals from the same breeding colony [1-4, 17]. All diabetic rats required daily insulin therapy.

\section{Islet cell surface antibodies and lymphocyte antibodies in low-incidence litters}

Sera samples obtained from the BB rats biweekly during the 104 days' study period showed that the binding of ${ }^{125} \mathrm{I}$-protein A to RIN 5F cells in the 26 low-incidence litter BB rats ranged between 551 and $11,258 \mathrm{cpm} /$ $10^{5}$ RIN $5 \mathrm{~F}$ cells. The one rat with insulitis deviated from the remaining 25 rats at $48-53$ days of age, the mean $+2 S D$ at this age for all 26 rats being 4691 $\mathrm{cpm} / 10^{5}$ RIN $5 \mathrm{~F}$ cells (Fig. 2). Calculation of the mean $+2 \mathrm{SD}\left(4578 \mathrm{cpm} / 10^{5} \mathrm{RIN} 5 \mathrm{~F}\right.$ cells $)$ of nine samples taken between the ages of 38-157 days detected two additional ICSA-positive rats, one with impaired glucose tolerance and one without impaired glucose tolerance or insulitis (Fig. 2). In the following analysis we define the presence of ICSA and lymphocyte antibodies as a binding value exceeding the mean $+2 \mathrm{SD}$ of all binding values obtained at the corresponding age in the 26 low-incidence litter rats.

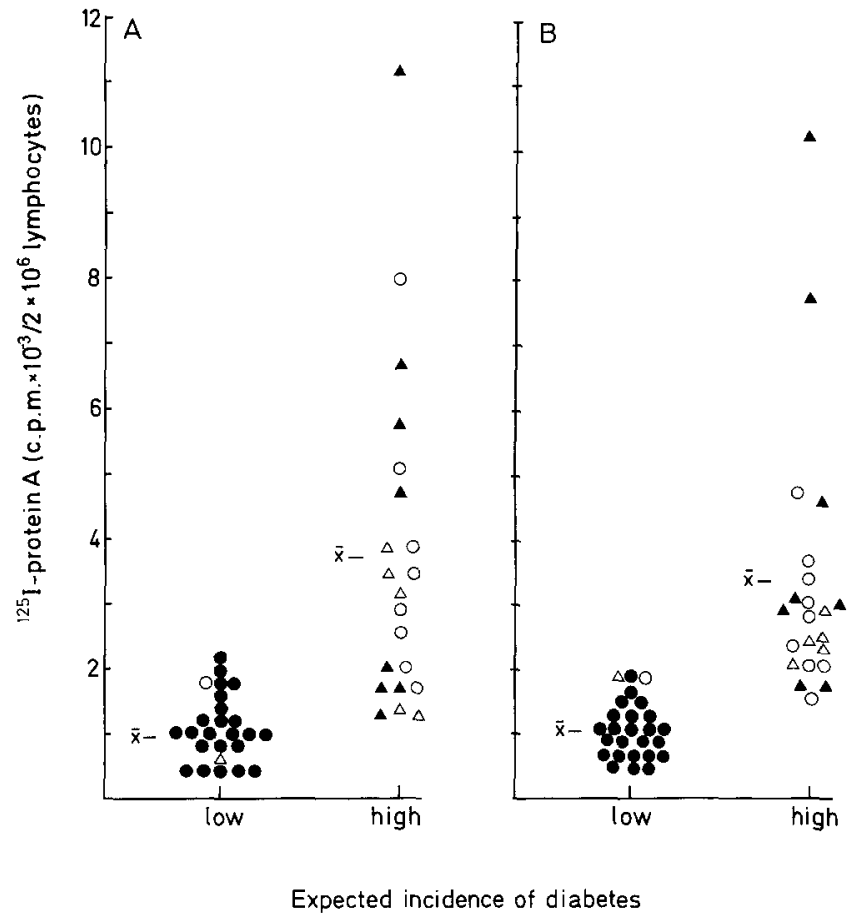

Fig. 3. Panel A: the binding of ${ }^{125}$ I-protein A to spleen lymphocytes, incubated in sera from low- and high-incidence BB rats, 48-53 days of age. Panel B: mean binding of 6-10 determinations of sera sampled bimonthly throughout the study (38-157 days). Symbols indicate rats without ( ) or, at the end of the study (142-157 days of age) with either insulin-dependent diabetes $(\Delta)$, impaired glucose tolerance $(\Delta)$, or insulitis $(O)$. The mean values $(\bar{x})$ for low- and high-incidence rats were significantly different in both age ranges $(p<0.001)$

\section{Islet cell surface and lymphocyte antibodies in high-incidence litters}

ICSA (Fig. 2) and lymphocyte antibodies (Fig.3) levels were increased among the high-incidence litter rats both at 48-53 days of age and as the mean of 6-10 measurements during 38-157 days of age. ICSA, as defined above, was found in 16 out of $22(73 \%)$ high-incidence litter rats compared to four out of $56(15 \%)$ among the low-incidence control rats $(p<0.002)$. All high-incidence rats $(22 / 22)$ had lymphocyte antibodies compared to five out of $26(19 \%)$ of the low-incidence rats $(p<0.002)$.

At $~ 50$ days of age, 8 out of $21(38 \%)$ rats in the high-incidence litters showed binding $>$ mean $+2 \mathrm{SD}$ (4691 cpm $/ 10^{5} \mathrm{RIN} 5 \mathrm{~F}$ cells) of the 26 low-incidence animals (Fig. 2A). When the mean binding values during 38-157 days of age were compared (Fig. 2 B), ICSA was present among $32 \%(7 / 22)$ of the high-incidence litter animals. These results suggest that there was no apparent relation between ICSA and diabetes, impaired glucose tolerance, or the end-point analysis of insulitis. The mean binding values in animals developing diabetes did not differ from rats with impaired glucose tolerance or end-point insulitis only. 


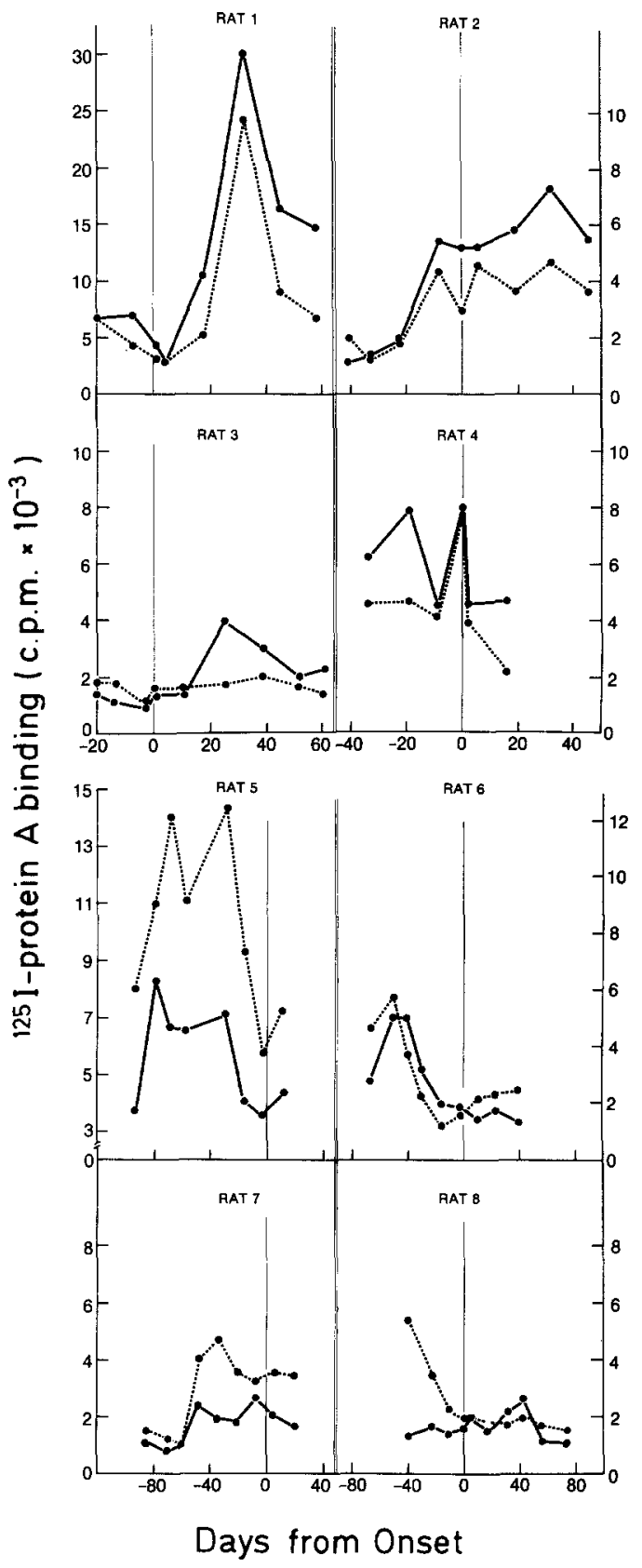

Fig.4. The time course of islet cell surface (- ) and lymphocyte antibodies (-) in the eight high-incidence rats which developed insulin-dependent diabetes. The animals were followed during the period of 38-157 days of age. The vertical line indicates the detection of insulin-dependent diabetes. The presence of antibodies is shown as the binding of ${ }^{125} \mathrm{I}$-protein A to either $10^{5}$ RIN $5 \mathrm{~F}$ cells or $10^{6}$ spleen lymphocytes

The analysis of lymphocyte antibodies demonstrated that $18 / 21(77 \%)$ of the high-incidence rats had antibodies at $48-53$ days (Fig. $3 \mathrm{~A}$ ). When the mean binding value for the entire period was considered, 19 rats were lymphocyte antibody-positive (Fig. 3 B). At 38 days of age, the earliest sampling time available, all high-incidence rats were lymphocyte antibody-positive $(10 / 10)$.

During the course of our study eight rats developed diabetes (Fig. 2 and 3). ICSA were found in four of
Table 2. Lymphocyte counts in the peripheral blood of high-incidence $\mathrm{BB}$ rats

\begin{tabular}{|c|c|c|c|}
\hline $\begin{array}{l}\text { Age } \\
\text { (days) }\end{array}$ & $\begin{array}{l}\text { Number } \\
\text { of rats }\end{array}$ & $\begin{array}{l}\text { Lymphocyte counts } \\
\text { in high-incidence } \\
\text { (lymphocytes/ } \\
\mu \text { l blood) }\end{array}$ & $\begin{array}{l}\text { Difference in lymphocyte } \\
\text { counts (high-incidence - } \\
\text { low-incidence) (lympho- } \\
\text { cytes/ul blood) }\end{array}$ \\
\hline 38 & 21 & $3108 \pm 234$ & $-635 \pm 265$ \\
\hline 53 & 22 & $2867 \pm 168$ & $-1024 \pm 168$ \\
\hline 63 & 22 & $3698 \pm 225$ & $-557 \pm 225$ \\
\hline 74 & 21 & $3964 \pm 148$ & $-3501 \pm 229$ \\
\hline 88 & 21 & $3891 \pm 230$ & $-3311 \pm 230$ \\
\hline 102 & 20 & $3962 \pm 281$ & $-3516 \pm 281$ \\
\hline 115 & 18 & $3772 \pm 327$ & $-3483 \pm 367$ \\
\hline 128 & 21 & $3801 \pm 307$ & $-2552 \pm 306$ \\
\hline 142 & 21 & $3882 \pm 251$ & $-4094 \pm 251$ \\
\hline
\end{tabular}

Results expressed as mean \pm SEM

these diabetic rats already at $48-53$ days of age and in three of them when expressed as the mean ICSA binding during 38-157 days (Fig. 2). Lymphocyte antibodies were positive in seven diabetic rats at $48-53$ days and in six of the eight diabetic rats when the mean binding value was considered (Fig. 3). The level of ${ }^{125}$ I-protein A binding to both RIN 5F cells and spleen lymphocytes varied considerably between individual diabetic rats (Fig. 4). Diabetic rats 1-3 showed peak ICSA and lymphocyte antibody values at or after diagnosis of diabetes, but in diabetic rat 1 both antibodies were present before diagnosis. In diabetic rats 4-7 (Fig.4) peak values occurred prior to the diagnosis. In diabetic rats 7 and 8 no samples were positive for ICSA, however, lymphocyte antibodies were present before diagnosis in both animals (Fig. 4). There was a linear relationship between ${ }^{125}$ I-protein A binding to RIN $5 \mathrm{~F}$ cells and lymphocytes $(r=0.75-0.98)$ in 5 out of 8 diabetic rats. Both ICSA and lymphocyte antibodies showed a trend towards lower binding values with increasing age in the eight diabetic rats.

\section{Lymphocytopenia}

All rats in the high-incidence litters showed lymphocytopenia (Table 2). There was no difference in lymphocyte number between animals that developed diabetes or impaired glucose tolerance or had insulitis only. In the observation period of 38-142 days of age all lymphocyte counts in the high-incidence litters were significantly lower than in the low-incidence litters (Table 2).

In a total of 194 sera from high-incidence litter rats, there was an overall significant linear correlation between ICSA and lymphocyte antibodies $(r=0.6638$, $p<0.001$ ). A highly significant linear correlation between ICSA and lymphocyte antibodies was observed both in the eight rats developing diabetes $(r=0.7920$, $p<0.001)$ and in the five rats with impaired glucose tolerance $(r=0.5065, p<0.001)$. In the five rats that developed impaired glucose tolerance, a negative linear correlation was found between lymphocyte antibodies and total lymphocyte counts $(r=-0.4029, p<0.01)$. 


\section{Discussion}

This study confirms and extends our previous observation that circulating antibodies to cell surface determinants on islet cells and spleen lymphocytes may be present in many BB rats at or after the diagnosis of diabetes [13]. The high level of antibody binding at the time of clinical diagnosis prompted us to monitor BB rats from the time of weaning up to 160 days of age. At this age the majority of the animals would be expected to have developed diabetes $[2,3]$. Utilizing $\mathrm{BB}$ rats from the original Ottawa colony $[3,17]$, it was possible to follow litters with expected high incidence of diabetes and compare them to litters with expected low incidence. This investigation, therefore, allowed us to determine, firstly, the natural history of ICSA, lymphocyte antibodies and blood lymphocyte counts together with metabolic parameters. Secondly, since it is controversial to what extent ICSA and/or lymphocyte antibodies are involved in the pathogenesis of insulin-dependent diabetes, our prospective analysis made it possible to test whether the antibodies preceded the onset of diabetes or were a consequence thereof. In this respect the BB rat offers a unique possibility to study the progression of events leading to a diabetic syndrome which in many respects resembles that of Type 1 (insulin-dependent) diabetes in man [3].

The large number of samples generated from a total of 48 animals followed prospectively for 104 days were analysed for ICSA with paraformaldehyde-fixed RIN $5 \mathrm{~F}$ cells. These cells represent a continuous insulinproducing rat cell-line which was cloned from insulinand somatostatin-secreting cell-lines established from a transplantable rat islet cell tumour [18]. The RIN 5F cells are reported to release insulin in response to a variety of beta cell secretagogues except glucose [28]. Nonspecies specific cytotoxic antibodies against the RIN 5F cells as well as the RIN 14B cells have been detected in sera from many patients with Type 1 (insulin-dependent) diabetes $[29,30]$. Antigenic determinants reactive with antibodies in both human and BB rat diabetic sera therefore seem to be present in the RIN 5F cells. Also it was found both previously [27] and in the present study that the binding activity in BB rat sera to RIN 5F cells correlated to that observed with dispersed normal Wistar rat islet cells. In addition, the adsorption experiments (Fig.1) demonstrate that RIN 5F cells but not splenic lymphocytes quantitatively adsorb the binding activity to the RIN $5 \mathrm{~F}$ cells. It was concluded that, as for human diabetic sera samples $[29,30]$, the RIN 5F cells represent suitable target cells for monitoring circulating rat ICSA. Another advantage in the present approach is the use of paraformaldehyde-fixed cells, which in contrast to living cells permit handling of many samples.

The increased frequency of positive tests and the high binding values to RIN 5F cells and to spleen lymphocytes in $\mathrm{BB}$ rats later developing morphological signs of insulitis, or of impaired glucose tolerance and/ or diabetes, suggest that these antibodies are early features of this syndrome. The causal relationship between the antibodies and the ensuing diabetes cannot be definitely resolved from this study. Our analysis (Fig. 4) indicates that ICSA and/or lymphocyte antibodies may not be present before the diagnosis of diabetes in all rats. However, ICSA correlated to lymphocyte antibodies in both diabetic and rats with impaired glucose tolerance but not in rats with insulitis alone. Also, in five rats with impaired glucose tolerance there was a negative correlation between lymphocyte antibodies and total numbers of lymphocytes. A long-term exposure to certain levels of ICSA and/or lymphocyte antibodies may therefore contribute to the development of both glucoregulatory disturbances and/or lymphocytopenia.

The ICSA reaction does not seem to be limited to pancreatic B cells since about $30 \%$ of the ICSA activity was removed by quantitative adsorption with spleen lymphocytes (Fig. 1) and since the somatostatin-producing RIN 14B cells (Oie and Gázdar, personal communication) showed ICSA after incubation in BB rat sera (Table 1). Eisenbarth and co-workers [29] found human diabetic sera also mediated complement-dependent antibody cytotoxicity against the RIN 14B cells. However, whereas somatostatin-producing cells (D cells) often remain in islets from patients with Type 1 (insulin-dependent) diabetes [31, 32], immunocytochemical analysis of the diabetic BB rat pancreatic islets revealed pathological changes of the $D$ cells also [33]. The pathogenesis of diabetes in the BB rat may therefore include other cells in addition to the $B$ cells and possibly a variety of antigenic determinants since not only ICSA and lymphocyte antibodies are detected in diabetes susceptible animals but also antibodies to thyroid, smooth muscle, and gastric parietal cells [14-16]. The BB rats may therefore have an abnormal immune response which predisposes to the development of insulin-dependent diabetes often in association with ICSA and/or lymphocyte antibodies but not dependent upon these autoantibodies.

Acknowledgments. The authors acknowledge Dr. P. Thibert for the animals used in this study and R. Olesen, C.-N.Wei, M. Grose, and A. N. Stein for excellent technical assistance. These studies were supported, in part, by grants from the National Institutes of Health (AM-26190), the Medical Research Council of Canada (MA-6540) and the Danish Medical Research Council. Thomas Dyrberg was a recipient of a research fellowship from the University of Copenhagen, Denmark.

\section{References}

1. Nakhooda AF, Like AA, Chappel CL, Furrey FT, Marliss EB (1977) The spontaneously diabetic Wistar rat. Metabolic and morphologic studies. Diabetes 26: 100-112

2. Nakhooda AF, Like AA, Chappel CL, Wei C-N, Marliss EB (1978) The spontaneously diabetic Wistar rat. Studies prior to and during development of the overt syndrome. Diabetologia 14 199-207 
3. Marliss EB, Nakhooda AF, Poussier P, Sima AAF (1982) The diabetic syndrome of the "BB" Wistar rat. Possible relevance to Type 1 (insulin-dependent) diabetes in man. Diabetologia 22: 225-237

4. Poussier P, Nakhooda AF, Falk JA, Lee C, Marliss EB (1982) Lymphopenia and abnormal lymphocyte subsets in the "BB" rat: relationship to the diabetic syndrome. Endocrinology 110: 1825-1827

5. Jackson R, Rassi N, Crump T, Haynes B, Eisenbarth GS (1981) The BB diabetic rat. Profound T-cell lymphocytopenia. Diabetes 30: 887-889

6. Kadison P, Jackson R, Rassi N, Haynes B, Jegasothy B, Eisenbarth GS (1982) The BB rat: Selective W3/25 T-cell lymphocytopenia and profound depression of mitogen responsiveness. Clin Res 30: 396A (Abstract)

7. Rossini AA, Mordes JP, Pelletier AM, Like AA (1983) Transfusions of whole blood prevent spontaneous diabetes mellitus in the BB rat. Science 219: 975-977

8. Like AA, Kislauskis E, Williams RM, Rossini AA (1982) Neonatal thymectomy prevents spontaneous diabetes mellitus in the $\mathrm{BB} / \mathrm{W}$ rat. Science 216: 644-646

9. Like AA, Rossini AA, Guberski DL, Appel MC, Williams RM (1979) Spontaneous diabetes mellitus: reversal and prevention in the $\mathrm{BB} / \mathrm{W}$ rat with antiserum to rat lymphocytes. Science 206 : $1421-1423$

10. Laupacis A, Gardell C, Dupre J, Stiller CR, Keown P, Wallace AC, Thibert $\mathrm{P}$ (1983) Cyclosporin prevents diabetes in BB Wistar rats. Lancet $1: 10-11$

11. Naji A, Silvers WK, Bellgrau D, Barker CF (1981) Spontaneous diabetes in rats destroys transplanted islets and is prevented by immunologic tolerance. Science 213:1390-1392

12. Nakhooda AF, Sima AAF, Poussier P, Marliss EB (1981) Passive transfer of insulitis from the "BB" rat to the nude mouse. Endocrinology 109: 2264-2266

13. Dyrberg T, Nakhooda AF, Baekkeskov S, Lernmark Å, Poussier P, Marliss EB (1982) Islet cell surface antibodies and lymphocyte antibodies in the spontaneously diabetic BB Wistar rat. Diabetes 31: $278-281$

14. Elder M, Maclaren N, Riley W, McConnell T (1982) Gastric parietal cell and other autoantibodies in the BB rat. Diabetes 31: 313-318

15. Like AA, Butler L, Williams RM, Appel MC, Weringer CJ, Rossini AA (1982) Spontaneous autoimmune diabetes mellitus in the BB rat. Diabetes 31 (Suppl 1): 7-13

16. Like AA, Appel MC, Rossini AA (1982) Autoantibodies in the BB/W rat. Diabetes 31: 816-820

17. Nakhooda AF, Poussier P, Marliss EB (1983) Insulin and glucagon secretion in BB Wistar rats with impaired glucose tolerance. Diabetologia 24: $58-62$

18. Gázdar AF, Chick WL, Oie HK, Sims HL, King DL, Lauris L (1980) Continuous, clonal insulin- and somatostatin-secreting cell-lines established from a transplantable rat islet cell tumor. Proc Natl Acad Sci USA 77: 3519-3523
19. Huen AH-J, Haneda M, Freedman ZR, Lernmark Å (1983) Quantitative determination of islet cell surface antibodies using ${ }^{125}$ I-protein A. Diabetes 32: 460-465

20. Moskalewski A (1965) Isolation and culture of the islets of Langerhans of the guinea pig. Gen Comp Endocrinol 5: 342-351

21. Lacy PE, Kostianovsky M (1967) Method for the isolation of intact islets of Langerhans from the rat pancreas. Diabetes 16: 35-42

22. Dyrberg T, Baekkeskov S, Lernmark Å (1982) Specific pancreatic $\beta$-cell surface antigens recognized by a xenogenic antiserum. $J$ Cell Biol 94: 472-477

23. Böyum A (1968) Isolation of mononuclear cells and granulocytes from human blood. Scand J Clin Lab Invest 21: 77-89

24. Lark PD, Craven BR, Bosworth RCL (1968) The handling of chemical data. Pergamon Press, Oxford, UK, p 55

25. Langone JJ (1978) ${ }^{125}$ I-protein A: A tracer for general use in immunoassay. J Immunol Methods 24: 269-285

26. Richman DD, Cleveland PH, Oxman MN, Johnson KM (1982) The binding of staphylococcal protein A by the sera of different animal species. J Immunol 128: 2300-2305

27. Dyrberg T, Lernmark $\AA$, Oie HK, Gázdar AF (1982) Islet cell surface antibodies in spontaneously diabetic BB rats. Acta Biol Med Germ 41: 1105-1109

28. Praz GA, Halban PA, Wollheim CB, Blandel B, Strauss AJ, Renold AE (1983) Regulation of immunoreactive insulin release from a rat cell line (RIN 5F). Biochem J 210: 345-352

29. Eisenbarth GS, Morris MA, Scearce RM (1981) Cytotoxic antibodies to cloned rat islet cells in serum of patients with diabetes mellitus. J Clin Invest 67: 403-408

30. Kende M, Dobersen MJ, Ginsberg-Fellner F, Notkins AL (1981) Insulinoma target cells for measurement of cytotoxic antibodies in patients with insulin-dependent diabetes mellitus. Diabetes 30 (Suppl 1): 65A

31. Orci L, Baetens D, Rufener C, Amherdt M, Ravazzola M, Studer P, Malaisse-Lagae F, Unger RH (1976) Hypertrophy and hyperplasia of somatostatin-containing D-cells in diabetes. Proc Natl Acad Sci USA 73: 1338-1342

32. Gepts W, LeCompte PM (1981) The pancreatic islets in diabetes. Am J Med 70: 105-115

33. Tannenbaum GS, Colle E, Wanamaker L, Gurd W, Goldman H, Seemayer TA (1981) Dynamic time-course studies of the spontaneously diabetic BB Wistar rat. II. Insulin-, glucagon-, and somatostatin-reactive cells in the pancreas. Endocrinology 109: $1880-1887$

Received: 25 April 1983

and in revised form: 31 October 1983

Dr. T. Dyrberg

Hagedorn Research Laboratory

Niels Steensensvej 6

DK-2820 Gentofte

Denmark 